Article

\title{
Submarine Depositional Terraces at Salina Island (Southern Tyrrhenian Sea) and Implications on the Late-Quaternary Evolution of the Insular Shelf
}

\author{
Daniele Casalbore ${ }^{1,2, *}$, Claudia Romagnoli ${ }^{3,2}$, Chiara Adami ${ }^{2}$, Alessandro Bosman ${ }^{2}$ (D), \\ Francesco Falese ${ }^{2}$, Alessandro Ricchi ${ }^{3}$ and Francesco Latino Chiocci ${ }^{1,2}$ \\ 1 Dipartimento Scienze della Terra, Sapienza Università di Roma, 00185 Roma, Italy; \\ francesco.chiocci@uniroma1.it \\ 2 Istituto di Geologia Ambientale e Geoingegneria, Consiglio Nazionale delle Ricerche, 00185 Roma, Italy; \\ claudia.romagnoli@unibo.it (C.R.); kiaradami@gmail.com (C.A.); alessandro.bosman@uniroma1.it (A.B.); \\ francesco.falese@uniroma1.it (F.F.) \\ 3 Dipartimento di Scienze Biologiche, Geologiche ed Ambientali, Università di Bologna, \\ 3340126 Bologna, Italy; alessandro.ricchi7@unibo.it \\ * Correspondence: daniele.casalbore@uniroma1.it
}

Received: 16 November 2017; Accepted: 9 January 2018; Published: 13 January 2018

\begin{abstract}
The integrated analysis of high-resolution multibeam bathymetry and single-channel seismic profiles around Salina Island allowed us to characterize the stratigraphic architecture of the insular shelf. The shelf is formed by a gently-sloping erosive surface carved on the volcanic bedrock, mostly covered by sediments organized in a suite of terraced bodies, i.e. submarine depositional terraces. Based on their position on the shelf, depth range of their edge and inner geometry, different orders of terraces can be distinguished. The shallowest terrace (near-shore terrace) is a sedimentary prograding wedge, whose formation can be associated to the downward transport of sediments from the surf zone and shoreface during stormy conditions. According to the range depth of the terrace edge (i.e., 10-25 m, compatible with the estimated present-day, local storm-wave base level in the central and western Mediterranean), the formation of this wedge can be attributed to the present-day highstand. By assuming a similar genesis for the deeper terraces, mid-shelf terraces having the edge at depths of $40-50 \mathrm{~m}$ and $70-80 \mathrm{~m}$ can be attributed to the late and early stages of the Post-LGM transgression, respectively. Finally, the deepest terrace (shelf-edge terrace) has the edge at depths of 130-160 m, being thus referable to the lowstand occurred at ca. $20 \mathrm{ka}$. Based on the variability of edge depth in the different sectors, we also show how lowstand terraces can be used to provide insights on the recent vertical movements that affected Salina edifice in the last $20 \mathrm{ka}$, highlighting more generally their possible use for neo-tectonic studies elsewhere. Moreover, being these terraces associated to different paleo-sea levels, they can be used to constrain the relative age of the different erosive stages affecting shallow-water sectors.
\end{abstract}

Keywords: prograding wedges; coastal areas; paleo sea-level; insular shelf; volcanic islands; multibeam bathymetry

\section{Introduction}

In the last few decades, recent advances in seafloor imagery systems enabled to extensively map the submarine flanks of volcanic islands in different geodynamic setting, revealing a large variability of landforms due to volcanic, tectonic, and erosive-depositional processes [1-8]. Until now, most of these studies focused on large-scale instability processes affecting volcanic flanks, mainly in relation to their associated tsunamigenic potential and geohazard assessment [9-12]. Only in the 
last years, some papers paid attention to the shallow-water areas around volcanic islands, where the morphological characteristics of the shelf (i.e., shelf width and depth of its edge) can be used: (a) to reconstruct the original extension of early volcanic centres in the development of the island, including deeply eroded submarine cones, with respect to subaerial main centres, and (b) to assess the vertical movements of the volcanic edifice that have occurred after the shelf formation due to erosion [13-17]. Regarding this, another geomorphological/stratigraphic marker for relative paleo-sea level reconstruction and assessment of vertical movement is the edge depth of prograding sedimentary wedges, forming morphological terraces (Submarine Depositional Terraces, SDT hereafter, [18-20]). These features are commonly found on insular shelves and tectonically-controlled margins and are made by oblique and/or sigmoidal foresets (with slope angles between $4^{\circ}$ and $20^{\circ}$, commonly more than $10^{\circ}$ ), generally sloping basinward. Their genesis has been associated to the downward transport of sediments from the surf zone and shoreface during stormy conditions [21,22]. A good match has been found between the depth of these terraces (commonly in the range of 15-60 m) and the upper 10-percentile of the local wave height distribution, evidencing the key role played by storm-wave base level in their formation [23].

The aim of this paper is to characterize, through the integration of high-resolution multibeam bathymetry and single-channel seismic profiles, the overall seismo-stratigraphic architecture of the insular shelf surrounding Salina Island, with particular reference to the suite of submarine depositional terraces here present. Specifically, we discuss the relationship between near-shore (edge at water depths of 10-25 m) and shelf-edge terraces (edge at water depths greater than $120 \mathrm{~m}$ ) and their use as paleo sea-level markers. This, in turn, can provide insights on the recent vertical movements that affected Salina edifice in the last $20 \mathrm{ka}$, as well as on the timing of the different erosive stages associated to the canyons that carve the steep flanks of the volcanic edifice.

\section{Data and Methods}

Data used for this research are high-resolution multibeam bathymetry and single-channel seismic profiles acquired since 1993 from the University Sapienza of Rome, University of Bologna and CNR-IGAG. Specifically, the bathymetry is the result of several surveys mainly carried out onboard the R/V Urania and Thetis (CNR), using multibeam systems working at frequency from 50 to $100 \mathrm{kHz}$ for the different bathymetric range; data has been recorded using a differential GPS system (for details on data acquisition and processing see [4]). Shallow-water areas (approximately in the first $50 \mathrm{~m}$ water depths) were surveyed aboard a small boat using a Teledyne Reson 7125 (400 kHz) multibeam system, recorded using a GPS-RTK positioning (for details on data acquisition and processing see [24]). All the processed data were merged and gridded using the kriging algorithm to produce Digital Elevations Models (DEMs), with cell-size ranging from $1 \mathrm{~m}$ within $100 \mathrm{~m}$ water depth to $25 \mathrm{~m}$ at greater depths.

Two sets of seismic profiles, generally acquired radially to the shelf were collected in 1993 and 2016, respectively. The first set was acquired using a Sparker 0.5-1 kJ aboard the catamaran Incaurina Marianna, positioned through GPS. Because of the low accuracy of GPS positioning, these profiles were successively relocated via homologous matching of features observed on seismic profiles and multibeam bathymetry. The second set was acquired in 2016 aboard the R/V Minerva1 using a Sparker source working at $0.5-1.5 \mathrm{~kJ}$; data were georeferenced using a differential GPS. The vertical resolution of Sparker profiles can be estimated in the order of some metres for both sets due to the emitted frequency and to the ringing effects. A sound velocity of $1500 \mathrm{~m} / \mathrm{s}$ has been adopted for time-depth conversion in the seismic profiles.

\section{Geological Setting}

Salina is one of the seven islands of the Aeolian Archipelago in the Southern Tyrrhenian Sea (Figure 1 inset). It is $962 \mathrm{~m}$ high and represents the uppermost part ( 16\%) of a large stratovolcano, whose base lies at ca. $1300 \mathrm{~m}$ of water depth (Figure 1a). 

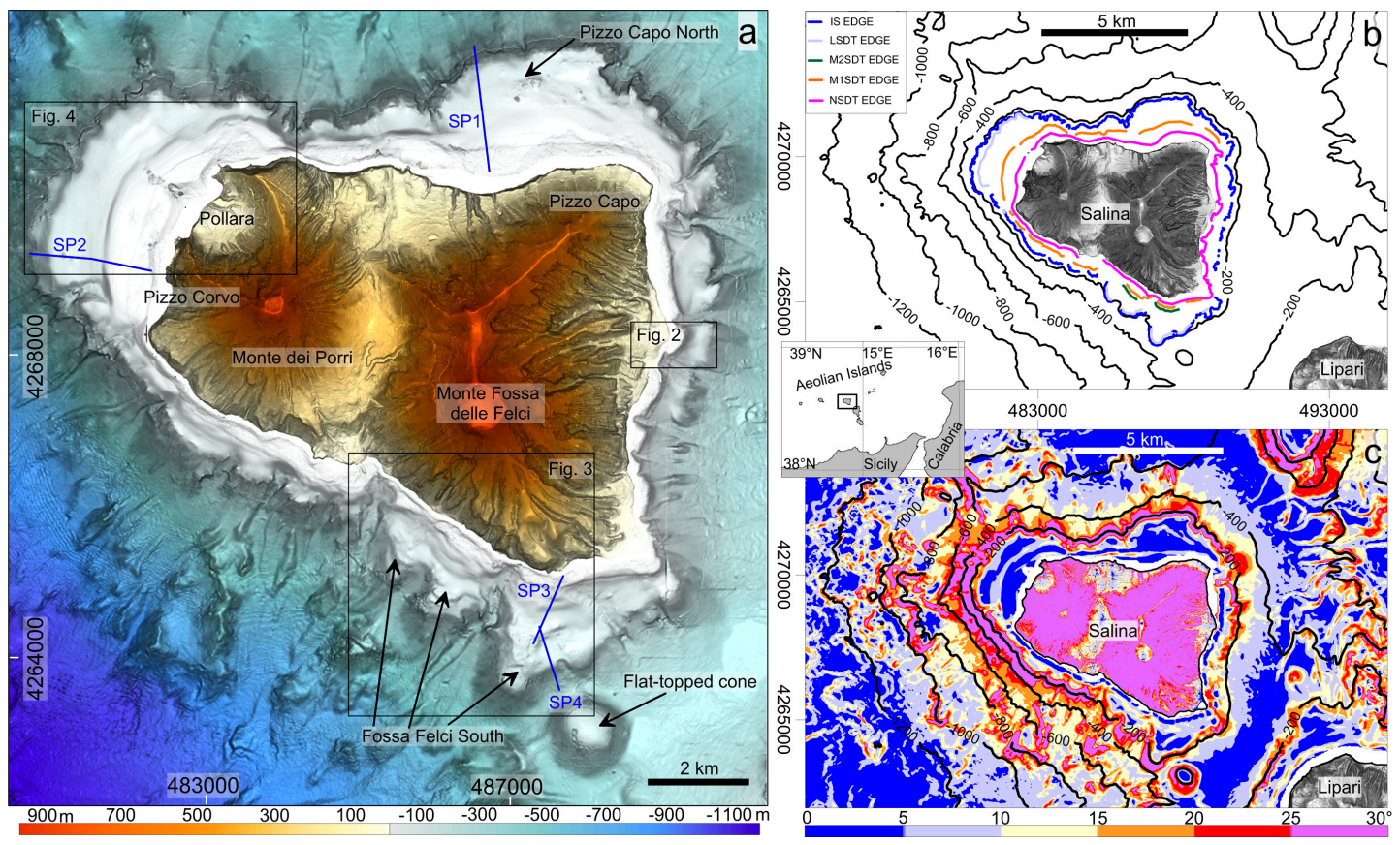

Figure 1. (a) Shaded relief of Salina Island and surrounding shelf, showing the location of Figures 2-4 (black boxes) and the trace of seismic profiles (blue lines) shown in Figures 5 and 6. Submarine eccentric centers of Pizzo Capo North and Fossa delle Felci South are also shown (from [17]). (b) Bathymetry (isobaths each $200 \mathrm{~m}$ ) with the mapping of the edge of the insular shelf (IS) and overlying submarine depositional terraces (NSDT: near-shore submarine depositional terrace; M(1/2)SDT: mid-shelf submarine depositional terrace; LSDT: shelf-edge (lowstand) submarine depositional terrace). (c) Slope gradient map of the Salina edifice in the southern Tyrrhenian Sea (for location see the inset).

Salina together with Lipari and Vulcano is part of an elongated volcanic belt, whose formation has been related to the occurrence of a main strike-slip NNW-SSE regional fault system, interpreted as the offshore prolongation of the "Tindari-Letojanni" fault, recognized onland in NE Sicily [25]. The volcanological evolution of Salina Island was summarized by [26], encompassing six Eruptive Epochs (EE) between $\sim 244$ and $15.6 \mathrm{ka}$. The products of the oldest EE are found in the NW and NE sectors of Salina, where the deeply eroded volcanic centres of Pizzo di Corvo (uncertain stratigraphic position and radiometric age) and Pizzo Capo (244-226 ka) are found (Figure 1c). Younger EE formed the Monte Fossa delle Felci (160-121 ka) and Monte dei Porri (70-57 ka) stratovolcanoes in the E and $\mathrm{W}$ part of the island, respectively (Figure 1c). Activity of the last EE is located at the Pollara crater in the NW part of Salina, where widespread rhyolitic pumiceous successions were emplaced between 30 and $15 \mathrm{ka}$ (Figure 1c). Raised marine terraces are found along the coasts of Salina, indicating an average uplift of $0.36 \mathrm{~m} / \mathrm{ka}$ for the island since the Last Interglacial [26]. Differently, the occurrence of an older MIS 7.3 terrace at lower elevations than MIS5 terraces was interpreted as the evidence of a subsidence phase affecting the early growth stages of Salina edifice before the Last Interglacial [26].

The submarine deeper flanks of the edifice (Figure 1a) are characterized by a complex seafloor morphology due to the presence of volcanic features (volcanic cones, lava flows, bedrock outcrops, for $\sim 30 \%$ of the overall extension) and erosive-depositional features (landslide scars, channels, fan-shaped deposits and waveforms, about $70 \%$, [27]). The shallower part of the submarine flank is cut by an insular shelf (Figure 1), clearly recognizable on the slope gradient map (Figure 1b), because of its gently declivities $\left(2^{\circ}-17^{\circ}\right.$, but typically less than $\left.5^{\circ}\right)$, interrupting the morphological continuity between the steeper $\left(>25^{\circ}\right)$ subaerial and submarine flanks of the edifice. It shows variable morphological characteristics; i.e., width and depth of the shelf edge around the island, suggesting indications on the development of the volcanic edifice [17]. The larger and deeper shelves are, in fact, 
observed along the W (Pizzo Corvo), NE (Pizzo Capo North) and SE (Fossa Felci South) sectors of the island, where the older volcanic activity is located (Figure 1c). Differently, narrow shelves with a shallower edge are observed around the younger Monte dei Porri edifice ( $\mathrm{N}$ and SW sectors of the island) as well as along the eastern flank of the island (Monte Fossa delle Felci), where the shelf is strongly dismantled by erosive-depositional processes due to a network of subaerial/submarine channels [27]. The erosive surface of the insular shelf is covered by sediments (mostly volcaniclastic and bioclastic deposits), organized in different orders of submarine depositional terraces $[20,22]$ that are the focus of the present paper.

Despite the commonly accepted influence of meteo-marine conditions in the formation of shelf ad overlying terraces, only few data are available for the Aeolian Islands in order to quantify their effects. On the whole, the most energetic wave climate in this sector is from westerly directions, since prevailing winds are from the NW or the W [17]. The western flank of Salina is struck by storms, with a typical fetch of 250-300 nautical miles and waves up to $6 \mathrm{~m}$ [17]. Winds from the SE also affect the south-eastern and eastern side of the Aeolian Islands, especially during the autumn and winter, whereas the southwestern sector is partially sheltered by the nearby Lipari Island.

\section{Results}

\subsection{Overall Morphology and Seismo-Stratigraphic Architecture of the Salina Insular Shelf}

The insular shelf around Salina Island is ca. 700-2000 m wide, extending from the coast down to the shelf edge, which is located at water depths ranging from ca. 110 to $225 \mathrm{~m}$ (Figure 1c; see also Table 1 of [17]). However, values of shelf width and depth of the shelf edge can be markedly lowered in the sectors affected by mass-wasting processes, as for instance along the eastern flank of the island (Figure 1c). The morphology of the shelf is generally characterized by a relatively smooth and flat surface, apart from the coastal areas where a more rugged morphology is present, as well as by different breaks-in-slope at higher depths, commonly oriented parallel to the contours and corresponding to the edge of submarine depositional terraces (Figures 1-4).

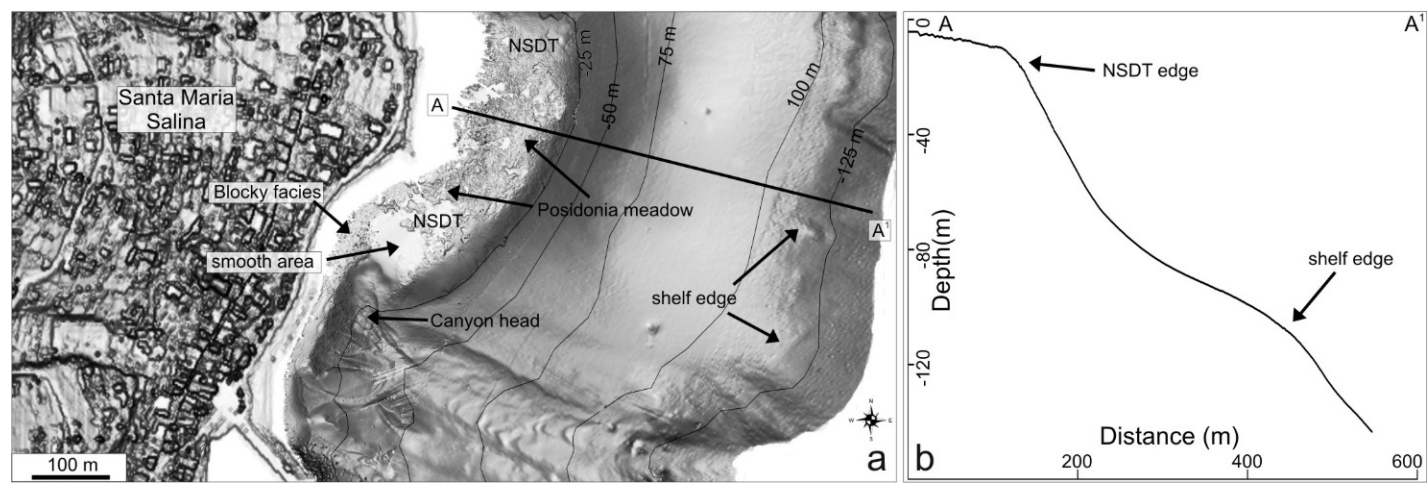

Figure 2. (a) Shaded relief map of the area around Santa Maria di Salina village in the eastern part of Salina (location in Figure 1a), where the near-shore submarine depositional terrace (NSDT) is visible in the inner shelf (first $25 \mathrm{~m}$ of depth); (b) the bathymetric cross-section $\mathrm{A}-\mathrm{A}^{1}$ shows the edge of the insular shelf and overlying NSDT.

The overall seismo-stratigraphic architecture of the shelf, although locally variable in the different sectors of the island, is typically characterized by an aggradational/progradational sedimentary wedge lying upon a relatively flat erosive surface cutting the volcanic bedrock, imaged as having high acoustic impedance and discontinuous echo type, with small diffraction hyperbolae (Figures 5 and 6). Five seismic units were recognized within the sedimentary wedge (Figures 5 and 6): four of these units (units 2-5) can be associated to terraced morphologies on the bathymetry (Section 4.2), whereas the 
lowermost unit 1 is rather discontinuous and thin (maximum thickness of $10 \mathrm{~m}$ ). Unit 1 is commonly found directly above the volcanic bedrock, especially in correspondence of morphological irregularities such as small depressions (SP2 in Figure 5 and SP3 in Figure 6). It is generally characterized by continuous or semi-continuous reflectors, with variable amplitude. The upper four seismic units are described with more detail in the next section, together with the related SDTs.

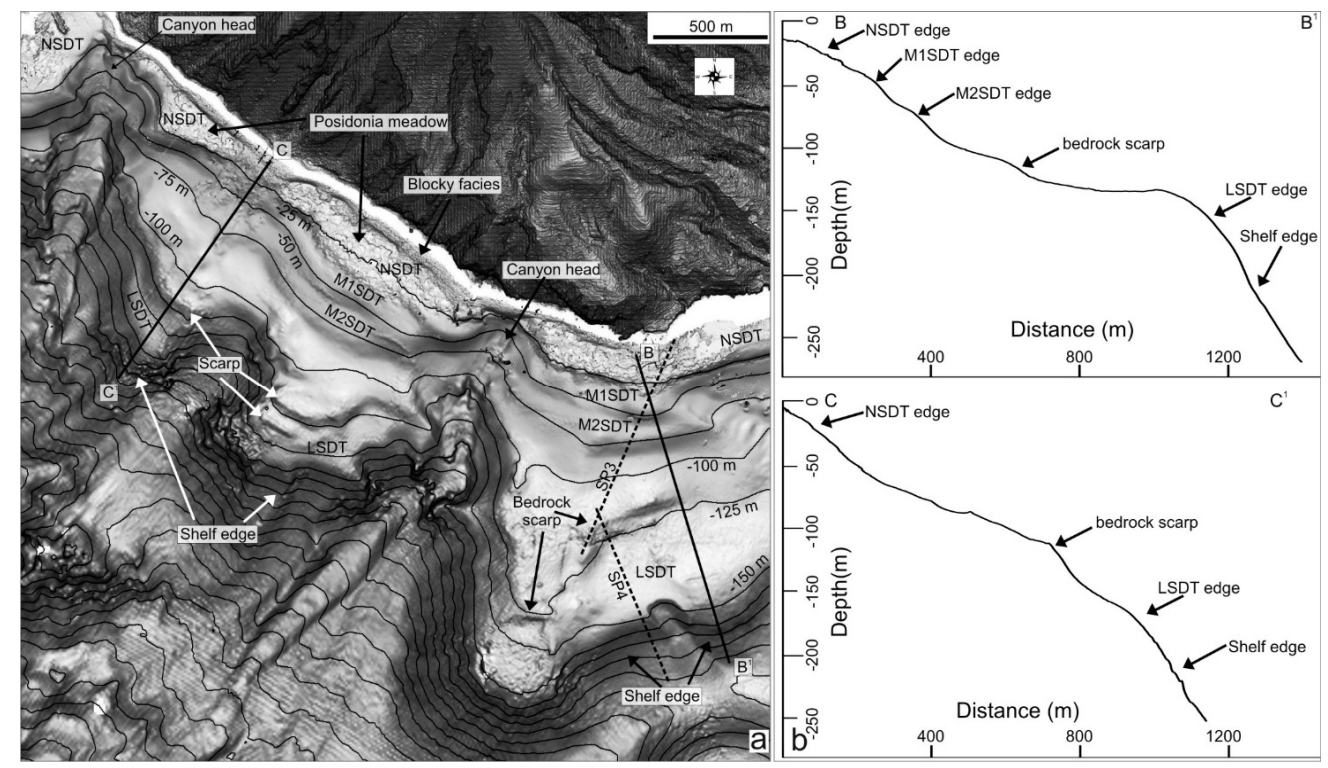

Figure 3. (a) Shaded relief map of the SE sector of Salina (location in Figure 1a), where a large shelf with different orders of submarine depositional terraces are present; (b) the bathymetric cross sections $B-B^{1}$ and $C-C^{1}$ evidence the edge depth of the shelf and overlying terraces. Note also the presence of two deeply indenting canyons that cut the shelf in very shallow-water areas, some tens of meters far from the coast. NSDT: near-shore submarine depositional terrace; M(1/2)SDT: mid-shelf submarine depositional terrace; LSDT: shelf-edge (lowstand) submarine depositional terrace. SP3 and 4 are the trace of the Sparker profiles shown in Figure 6.

\subsection{Submarine Depositional Terraces}

Submarine depositional terraces on the Salina shelf can be grouped in three main orders (near-shore, mid-shelf and shelf-edge terraces) according to their position on the shelf, depth of their edge (rollover depth) and associated seismic unit:

(a) the shallowest terrace (near-shore submarine depositional terrace, NSDT hereafter) has the edge at water depths of ca. 10-25 m (on average $15 \mathrm{~m}$ ) and is morphologically recognizable all along the island, even if it is more evident in the eastern and south-eastern sectors (NSDT in Figures 2 and 3, respectively). This terrace commonly shows an uneven morphology due to the alternation of smooth areas (corresponding to sandy seafloor with ripples, as deduced from direct check or through backscatter data) and blocky facies (often forming small ridges parallel to the coastline) or Posidonia Oceanica meadows (Figures 2-4), widely diffused on the terrace top.

Few seismic profiles cross this terrace because of its shallow depths and proximity to the coastline (tens or few hundreds of meters far from the coastline; Figures 2-4), hindering the manoeuvrability of towed seismic devices. The available profiles for NSDT (see, for instance, SP1 in Figure 5 and SP3 in Figure 6) show an uppermost seismic unit [5] characterized by an inner prograding geometry, with foresets downlap on a high-amplitude reflector, commonly representing the top of the underlying mid-shelf terrace; unit 5 has a maximum thickness of $18 \mathrm{~m}$ ( $10 \mathrm{~m}$ on average).

It has to be considered that the geometry of the near-shore terrace is often difficult to define on seismic profiles because its small thickness is partially masked by ringing effects generated by the 
Sparker source, and by chaotic echo type/low signal penetration due to occurrence of the blocky facies and Posidonia Oceanica meadows (Figures 2-4);

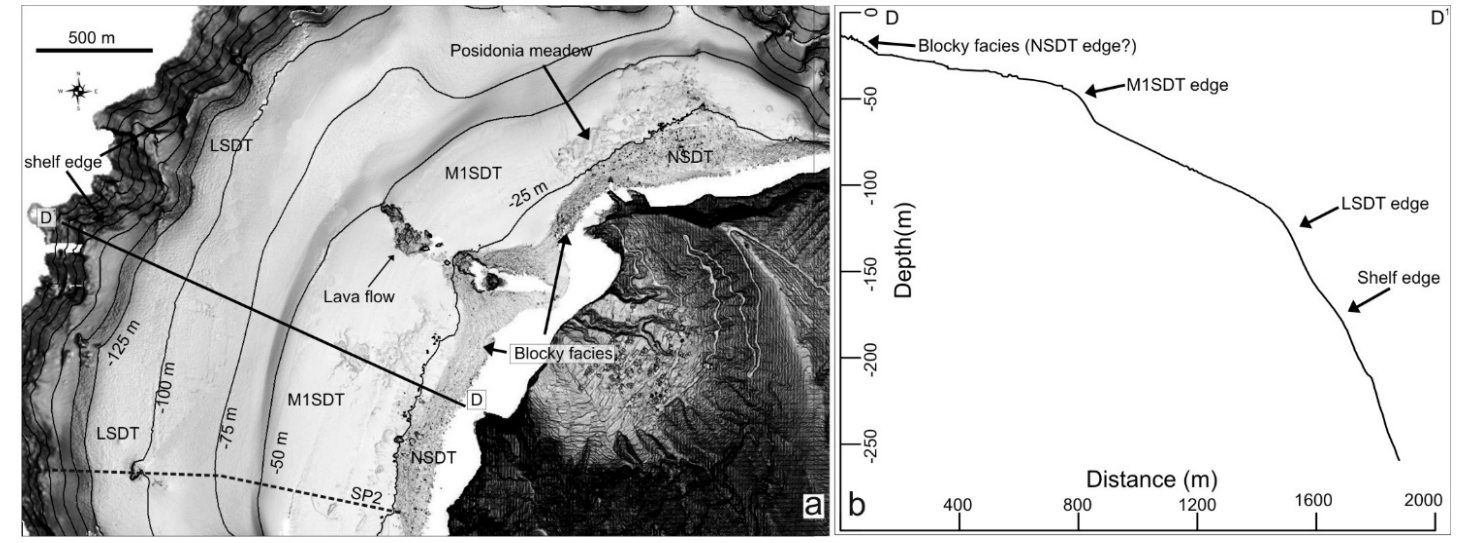

Figure 4. (a) Shaded relief map of the NW sector of Salina (location in Figure 1a), where a large shelf with different orders of submarine depositional terraces are present; $(\mathbf{b})$ the bathymetric cross section D-D ${ }^{1}$ shows the edge depth of the shelf and overlying terraces. In this area, the blocky facies forms a small ridge parallel to the coastline, characterized in cross-section $\mathrm{D}-\mathrm{D}^{1}$ by a convex-upward shape similar to the other submarine depositional terraces, having the edge at water depths around $15 \mathrm{~m}$. NSDT: near-shore submarine depositional terrace; M1SDT: mid-shelf submarine depositional terrace; LSDT: shelf-edge (lowstand) submarine depositional terrace. SP2 is trace of the Sparker profile shown in Figure 5.

(b) the mid-shelf terraces have the outer edge at depths around 40-50 m (M1SDT) and 70-80 m (M2SDT), even if minor and local slope breaks are recognizable on the bathymetry at different depths (always shallower than $-120 \mathrm{~m}$ ). The M1SDT edge is well-recognizable in the N, NW and SE sectors of the island (Figures 1c, 3 and 4), whereas the M2SDT edge is well-recognizable only in the S and SE sector of the island (Figure 3); both edges are not recognizable in the eastern sector (Figure 2).

On seismic profiles, the mid-shelf terraces M1SDT and M2SDT can be associated to the seismic units 4 and 3, respectively (Figures 5 and 6). Despite both seismic units occur on the entire shelf of Salina and are characterized by continuous and medium-high amplitude reflectors, they show a variable inner geometry in the different shelf sectors (Figure 5). Their geometry can vary from prograding (SP2 in Figure 5), with the topsets / foresets rollover forming a marked morphological edge of the terrace on the bathymetry (W sector, Figures 1c and 4), to more tabular, with the occasional recognition of onlapping reflectors on the volcanic bedrock (SP1), where the terrace edge is morphologically less marked (N sector, Figure 1c) or totally absent, such as in the eastern sector of the island (Figures 1c and 2). In a few cases, the morphological expression of a deeper terrace can be masked by the overlying terrace, if the vertical projections of the rollover associated to the two units matches (see SP2 in Figure 5). The thickness of these units is highly variable in the different sector of the shelf, being comprised between 5 and $20 \mathrm{~m}$ for the unit 4 and between 10 and $30 \mathrm{~m}$ for the unit 3;

(c) the shelf-edge terrace (LSDT in Figures 3 and 4) is recognizable only in the NW and SE sectors of the edifice, with an edge at water depths variable from 130 (cross-section $\mathrm{D}^{-\mathrm{D}^{1}}$ in Figure 4 ) to 150-160 m (cross sections B-B $B^{1}$ and $C-C^{1}$ in Figure 3 ).

On seismic profile, this terrace is associated to seismic unit 2, characterized by a marked prograding geometry, with steep foresets $\left(8^{\circ}-20^{\circ}\right)$ or with weakly transparent facies. Where very steep, these foresets cannot be imaged on seismic profiles since they appear acoustically transparent (see SP4 in Figure 6; see also [28]). This unit mainly lies above the volcanic bedrock, in the sectors where the erosive shelf edge is deeper than 160 m (section B-B' in Figure 3 and SP2 in Figure 5; section D-D' in Figure 4 and SP4 in Figure 6c,d). The seismic unit 2 shows a variable thickness, reaching a maximum value of $27 \mathrm{~m}$ in the SE sector. 


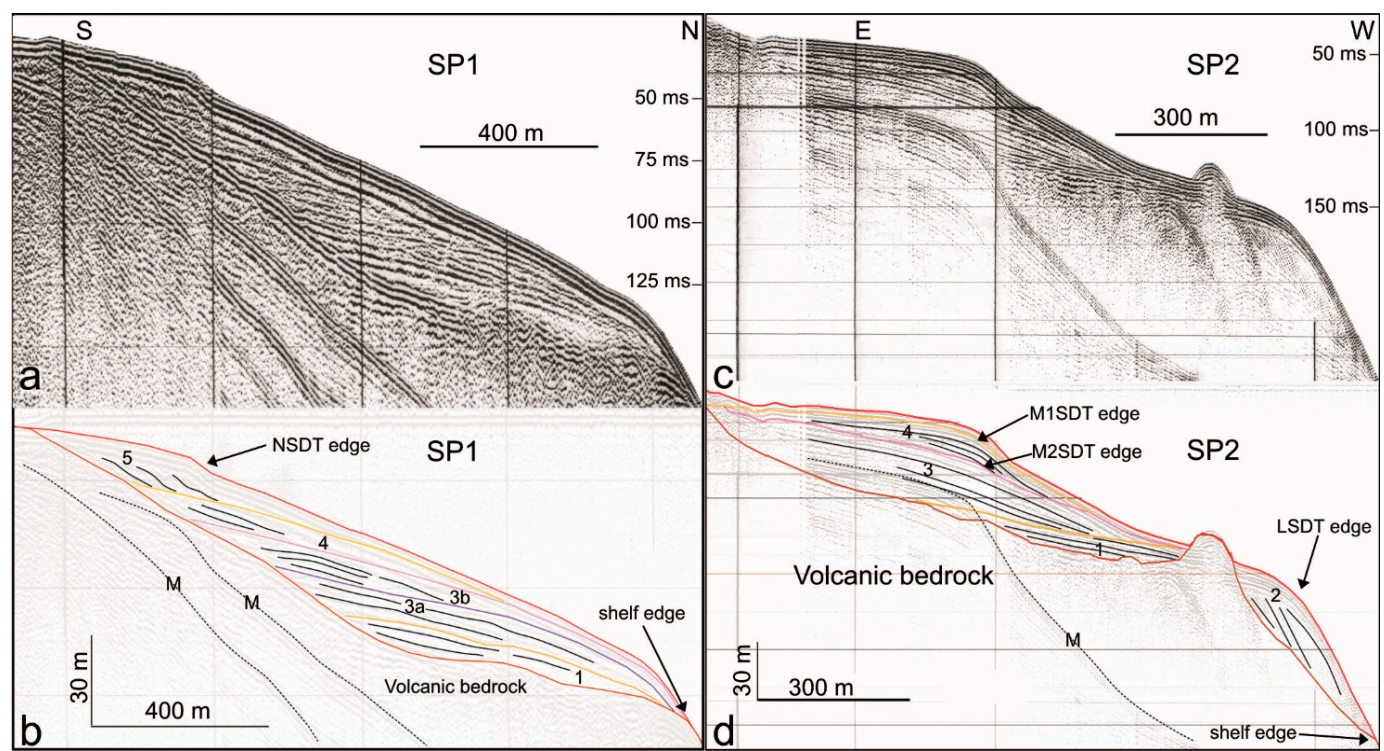

Figure 5. Sparker profiles $(\mathbf{a}, \mathbf{c})$ and associated line drawing $(\mathbf{b}, \mathbf{d})$ showing the stratigraphic architecture of the insular shelf on the northern (SP1) and western (SP2) part of Salina (for location see Figure 1a). The edge of the submarine depositional terraces (i.e., the rollover depth of the associated prograding units) are also shown. A sound velocity of $1500 \mathrm{~m} / \mathrm{s}$ has been adopted for time-depth conversion. Acronyms as in the previous figure, see text for details.

Finally, it should be considered that each of the above-mentioned terraces and associated seismic units can be locally affected by landslide scars (often representing the head of underlying submarine canyons) that can reduce their width and makes shallower the terrace edge with respect to the surrounding areas (Figures 1c, 2 and 3).

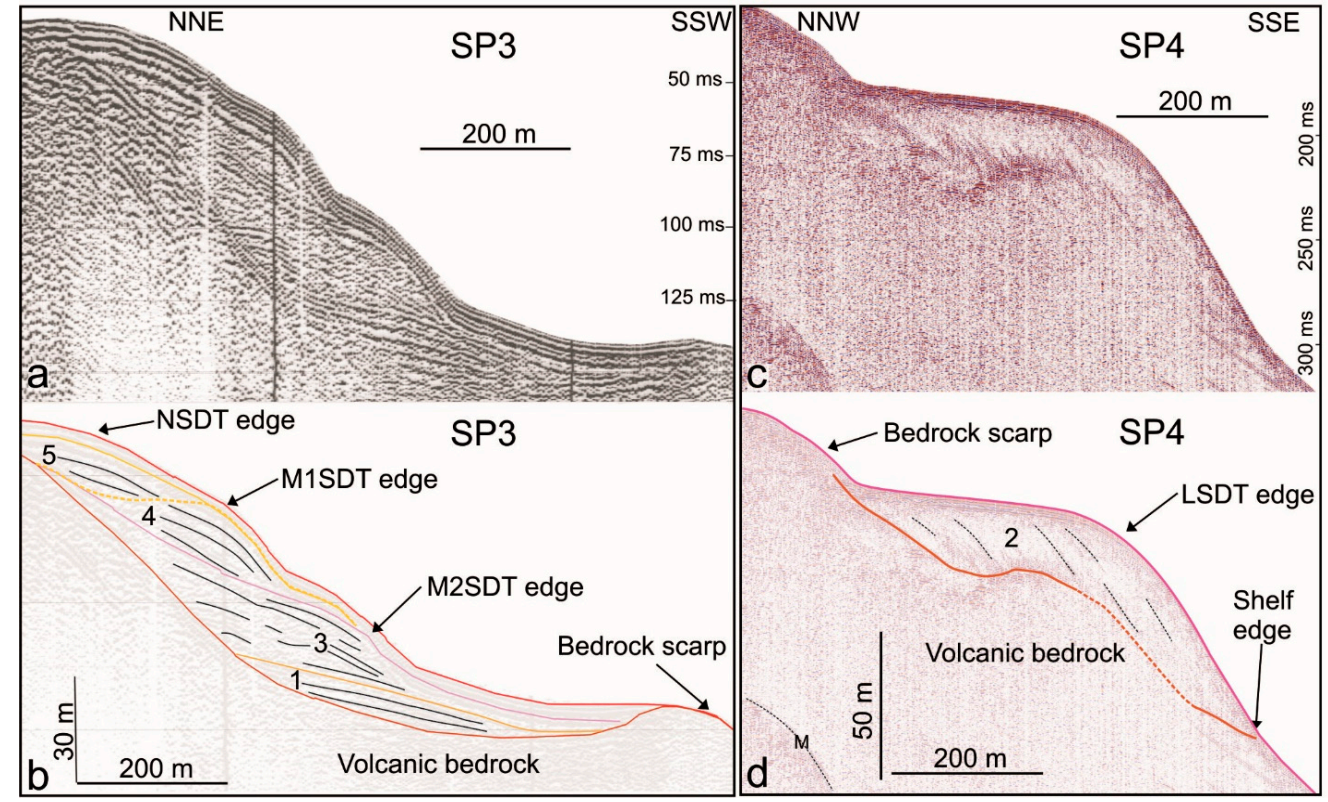

Figure 6. Sparker profiles $(\mathbf{a}, \mathbf{c})$ and associated line drawing $(\mathbf{b}, \mathbf{d})$ showing the stratigraphic architecture of the insular shelf on the south-eastern part of Salina (for location see Figure 1a). The edge of the submarine depositional terraces (i.e., the rollover depth of the associated prograding units) are also shown. A sound velocity of $1500 \mathrm{~m} / \mathrm{s}$ has been adopted for time-depth conversion. Acronyms as in the previous figure, see text for details. 


\section{Discussion}

\subsection{Late-Quaternary Evolution of Insular Shelf and Overlying Submarine Depositional Terrace}

The integration of morpho-bathymetric data and single-channel seismic profiles allows us to reconstruct the overall stratigraphic architecture of the shelf surrounding Salina Island, with particular attention to the development of terraced prograding wedges, i.e. submarine depositional terraces. These prograding wedges lie above an erosive surface that was carved on volcanic bedrock (Figures 5 and 6) and interpreted as the result of cumulated marine erosion on the flanks of subaerial/shallow-water volcanic centres during stages of reduced or inactive volcanism over different eustatic cycles [17]. At Salina, the shelf edge is commonly at depths comparable or shallower than the maximum depth of $-127 \mathrm{~m}$ reached by the sea level in the last $450 \mathrm{ka}$ [29], even if these values are not corrected for glacio-hydro-isostatic effect), in agreement with the regional uplift that characterizes the Aeolian Islands since the Last Interglacial, as witnessed by raised terraces [26]. Differently, the shelf edge is markedly deeper in the older W and SE sectors of the edifice, suggesting that subsidence affected Salina in the early growth stages [17].

The different orders of submarine depositional terraces identified in this study have been presumably formed during the last hemi-eustatic cycle (last $20 \mathrm{ka}$ ) that left its imprint over all shelf areas. In detail, the near-shore terrace is very similar in size and depth of its edge to present-day examples of prograding wedges observed on others insular shelves along the Mediterranean area, such as in the other Aeolian Islands [22] and the Pontine Archipelago [18,30] as well as along tectonically-controlled continental margins of Southern Iberia (infralittoral prograding wedge, [31]) and Southern Italy [32]. The depth range $(10-25 \mathrm{~m})$ of these edges is, in fact, compatible with the estimated present-day, local storm-wave base level in the central and western Mediterranean $[20,21,33]$, whereas it is markedly lower with respect to the edge of similar features observed around oceanic islands, where the storm-base level is deeper $[13,14,23]$. Based on such evidences and considering that the present-day level has been attained since ca. $6.5 \mathrm{ka}$ according to the sea level curve of [34], the formation of this terrace has been associated to the present highstand phase and, more generally, can be considered still under formation (Figure 7, [20]).

By applying the same genetic model to the deeper terraces, they can be interpreted as prograding wedges formed during stillstands, when the sea level was lower than the present-day. According to the sea-level curve of [34] and assuming similar meteo-marine conditions also for past sea-level conditions (on average $15 \mathrm{~m}$ for the storm-wave base level), the mid-shelf terraces 1 (edge at 40-50 m water depths) and 2 (edge at 70-80 m water depths) could have formed during the final and intermediate part of the transgressive phase (Figure 7). Even if we are aware that meteo-marine conditions could have been different during the Pleistocene and Holocene, as witnessed by some storm-wave deposits in the central and western Mediterranean [35,36], the possible difference in the depth range of $\pm 10 \mathrm{~m}$ is not enough to significantly change their stratigraphic attribution. Finally, the deeper shelf-edge terrace (edge at 130-160 m water depths) could have formed during the last lowstand at around $20 \mathrm{ka}$ (Figure 7), before the sea level rapidly rose. However, the depth variability of its edge is quite large and suggests the possible role of post-depositional vertical movements (discussed in the next section), although a part of this variability could be also due to the different oceanographic regime between the two sectors.

This stratigraphic attribution is also in agreement with a) the observed retrogradational pattern of the SDTs from the shelf edge (LSDT) to the inner shelf (NSDT), and b) the different seismic geometry observed for LSDT and NSDT (prograding geometry, typical of longer stillstand of the sea level, as during the lowstand and highstand phases) with respect to the MSDTs (from prograding to more tabular, with the recognition of onlapping reflectors on the ravinement surface, typical of transgression phase, [22]). Differently, the lowermost unit 1, showing a patchy distribution and small thickness, could be interpreted as composed of regressive deposits, formed during the falling stage before the 
LGM and locally preserved on the shelf, in correspondence of morphological steps or local depressions in the bedrock [37].

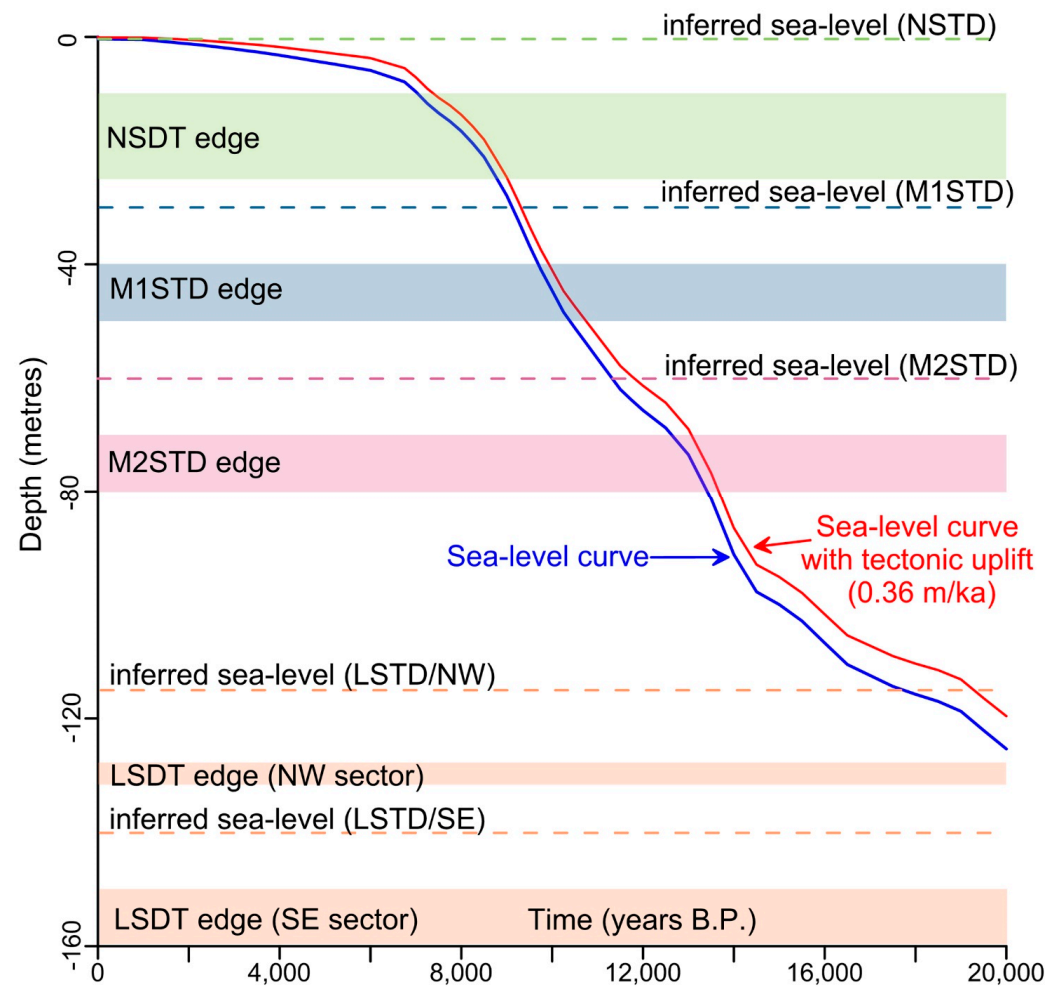

Figure 7. Plot of depth range of the submarine depositional terrace edges observed at Salina, with respect to the sea-level curve isostatically corrected for the last $20 \mathrm{ka}$ (blue line, from [34]) and that (red line) modified for a tectonic uplift of $0.36 \mathrm{~m} / \mathrm{ka}$ [26]. The inferred paleo sea-level (horizontal dashed lines) corresponding to the different terraces is also shown; this value was obtained by subtracting $15 \mathrm{~m}$ (average storm-wave base level at Salina) from the average depth of the terrace's edge. Note that two lines of inferred sea-level are drawn for LSDT in the NW and SE sectors, because of the large difference in depth range between the LSDT edge, suggesting the occurrence of differential vertical movements (see text for details). Acronyms as in the previous figures; B.P. $=$ Before Present.

\subsection{Submarine Depositional Terraces as a Tool for the Assessment of Vertical Movements and Relative Dating of Erosive Activity of Canyons}

In the previous section, we have inferred that the SDT's edge can be used as a proxy of sea-level position (dashed lines in Figure 7). However, we are aware that this depth is not a direct measure of the sea-level, but it is influenced by different factors, such as the storm-wave base level that varies in response to submarine morphology, coastal physiography and exposition (fetch, winds and wave regime). Moreover, its determination is influenced by mapping procedures (for a review of possible inaccuracies in the estimate, see [20]). By considering the variability of the present-day NSDT edge (10-25 m, on average $15 \mathrm{~m}$ ), we can roughly estimate an error range in the order of several meters. This means that only larger variations in the edge depths of a SDT could be related to differential vertical movements between two (or more) coastal sectors. This error estimation thus suggests excluding the NSDT for the vertical mobility assessment, because the amount of expected vertical movements in a time span of about 6.5 ka would be small (i.e., some meters at maximum) and, consequently, within the error range. Moreover, the NSDT is considered under formation at present, so possible changes in the depth of its edge due to vertical movements could be "readjusted" by active sedimentary dynamics [20]. Differently, the older M1SDT and M2SDT (the formation of which is roughly corresponding to inferred sea-level around 9 and $12 \mathrm{ka}$ in Figure 7) could be 
more promising for such assessment. However, mid-shelf terraces are commonly characterized by a large variability in inner geometry (from prograding to more tabular, with onlapping reflectors) and external shape (Section 4.1, Figures 5 and 6), posing some limits on their comparison among different sectors. The shelf-edge (lowstand) terrace shows instead a constantly, prograding inner geometry and a well-defined morphological edge, thus allowing a comparison at the island scale. On the other hand, where preserved, this terrace shows a larger range of edge depth: in the NW sector of Salina the edge is around $130 \mathrm{~m}$ water depth, being 20-30 m shallower than in the SE sector (150-160 m water depth), suggesting the occurrence of differential movements between these two sectors. The depth of LSDT edge in the NW sector is comparable with the predicted depth of the sea level during the last lowstand (Figure 7, around $120 \mathrm{~m}$ water depth, with a maximum value of $125 \mathrm{~m}$ at the LGM; [34]), also considering the average uplift rate of $0.36 \mathrm{~m} / \mathrm{ka}$ estimated for the island since the Last Interglacial [26] and accounting for ca. $7 \mathrm{~m}$ of vertical displacement in the last $20 \mathrm{ka}$. Differently, the depth of LSDT edge in the SE sector is deeper than the predicted sea level during the LGM. In particular, even if we subtract a maximum value of $25 \mathrm{~m}$ of storm-wave base level (derived from the range depth of the NSDT edge in order to perform a conservative analysis) from the depths of the LSDT edge in the SE sector, we obtain an inferred sea-level value of $130 \pm 5 \mathrm{~m}$, indicating a local subsidence of about $10 \mathrm{~m}$ occurred in the last $20 \mathrm{ka}$. This subsidence could be supported by the fact that the LSDT in the SE sector lies above an insular shelf cutting the top of submarine eccentric centers (named Fossa delle Felci South in Figure 1). This subsidence is also testified by the recognition of a nearby flat-topped cone (Figure 1c), characterized by a relatively flat erosive shelf, with edges at depths around $-220 \mathrm{~m}$ and covered by ca. $25 \mathrm{~m}$ of sedimentary cover [17], possibly affected by local vertical movements. These eruptive centres were emplaced close to the Lipari-Salina Channel, separating Salina from Lipari island, where more than $200 \mathrm{~m}$ of sediments (mostly with an aggradational pattern) were accumulated in a perched basin (unpublished data), suggesting that this sector has been also affected by a significant subsidence during time. Moreover, local evidence of subsidence, contrasting with the general uplift trend derived by raised marine terraces for the last $127 \mathrm{ka}$, have been also observed for the last few millennia at Panarea [38] and Lipari [22,39-41], in some coastal and shallow-water sectors.

Besides vertical mobility assessment, submarine depositional terraces can be also used for the relative dating of mass-wasting events affecting the insular shelf, on the basis of the geometrical relationship between them. In general, submarine canyon heads or landslide scars affecting a SDT, and being characterized by a marked morphological freshness, are thought to represent erosive stages occurring after the emplacement of the terrace. In contrast, the low morphological freshness of some canyon head and slide scar could be interpreted as the result of a successive draping or burial from the SDTs, thus indicating an older erosive stage. In this regard, attention should be paid to erosive features affecting the near-shore submarine depositional terrace (see for instance Figures 2 and 3), since the genesis of this latter can be referred to the present high-stand, this can represent a proxy for the occurrence of very recent mass-wasting events. A similar methodological approach has been tentatively applied to other Aeolian edifices (Stromboli and Lipari, [12,42]), and to tectonically-controlled margins [43], providing useful insights for a first geohazard assessment of the facing coastal areas.

\section{Final Remarks}

In summary, the present study allowed to characterize the complex seismo-stratigraphic architecture of the shelf surrounding Salina Island, that is strongly dependent on the interplay between local physiography, vertical movements, sediment supply, wave regime and sea-level fluctuations. This architecture is mostly made up by a series of terraced features (near-, mid- and shelf-edge terraces) associated to seismic units with an inner prograding geometry (sometimes tabular, with onlapping reflectors for mid-shelf units), whose genesis can be referred to the different sea-level phases (highstand, transgressive and lowstand) developed in the last hemi-eustatic cycle (i.e., post $20 \mathrm{ka}$ ). 
We suggest that these terraces (specifically, their edge/rollover depth) can be used as proxy for paleo seal-level position, even if affected by significant inaccuracies, that have been estimated in the order of several meters for the Salina case. Despite these inaccuracies, the large depth range of the lowstand submarine depositional terraces edge observed between the NW and the SE sectors of Salina, can be interpreted as the evidence of later vertical displacements (here possibly due to neo-tectonic). Therefore, this study highlights the potential role of SDTs for the assessment of vertical movements in volcanic or tectonically-controlled margins. Furthermore, SDTs can be also used to relatively date the main erosive stages of submarine canyons indenting the insular shelf, through the geometrical relationship between these features. Specifically, the near-shore (highstand) terraces have the potential to evidence the occurrence of (very) recent mass-wasting events affecting shallow-water areas often very close to the coasts, with significant implications on related geohazard assessment.

Acknowledgments: We gratefully acknowledge the National Research Council and the MaGIC Project funded by the Department of Civil Protection for the collection of geophysical data in deep water (Multibeam and seismic lines). Filippo Muccini and Riccardo Vagni are acknowledged for their assistance during the multibeam survey in very shallow water (in the framework of DPC-INGV Project V3) and the Ritmare project for the implementation of the multibeam equipment. Ministero dell'Ambiente e della Tutela del Territorio e del Mare-Geoportale Nazionale with license Creative Commons 3.0 Italy (CC BY-SA-3.0IT) for providing the terrestrial LIDAR data. The first author would also thank the funding provided by Progetto di Ateneo 2016 from Sapienza, University of Rome. Thanks to three anonymous reviewers for their constructive comments on the manuscript.

Author Contributions: Daniele Casalbore coordinated the overall study, and together with Claudia Romagnoli and Francesco Latino Chiocci, developed the main hypotheses regarding the formation of the submarine depositional terraces and their possible use for neo-tectonic studies and to constrain the relative age of the different erosive stages affecting shallow-water sectors. Daniele Casalbore and Claudia Romagnoli wrote the main text. Daniele Casalbore, Claudia Romagnoli, Chiara Adami, Francesco Falese, Alessandro Ricchi, and Alessandro Bosman analyzed the data. Daniele Casalbore together with Chiara Adami prepared the images shown in the text.

Conflicts of Interest: The authors declare no conflict of interest.

\section{References}

1. Mitchell, N.C.; Masson, D.G.; Watts, A.B.; Gee, M.J.R.; Urgeles, R. The morphology of the submarine flanks of volcanic ocean islands. A comparative study of the Canary and Hawaiian hotspot islands. J. Volcanol. Geothe. Res. 2002, 115, 83-107. [CrossRef]

2. Coussens, M.; Wall-Palmer, D.; Talling, P.J.; Watt, S.F.L.; Cassidy, M.; Jutzeler, M.; Clare, M.A.; Hunt, J.E.; Manga, M.; Gernon, T.M.; et al. The relationship between eruptive activity, flank collapse, and sea level at volcanic islands: A long-term >1(Ma) record offshore Montserrat, Lesser Antilles. Geochem. Geophys. Geosyst. 2016, 17, 2591-2611. [CrossRef]

3. Coombs, M.L.; White, S.M.; Scholl, D.W. Massive edifice failure at Aleutian Arc volcanoes. Earth Planet. Sci. Lett. 2007, 256, 403-418. [CrossRef]

4. Romagnoli, C.; Casalbore, D.; Bortoluzzi, G.; Bosman, A.; Chiocci, F.L.; D'Oriano, F.; Gamberi, F.; Ligi, M.; Marani, M. Bathy-morphological setting of the Aeolian Islands. In The Aeolian Islands Volcanoes; Geological Society of London: London, UK, 2013; pp. 27-36.

5. Nomikou, P.; Papanikolaou, D.; Alexandri, M.; Sakellariou, D.; Rousakis, G. Submarine volcanoes along the Aegean volcanic arc. Tectonophysics 2013, 597, 123-146. [CrossRef]

6. Bosman, A.; Casalbore, D.; Romagnoli, C.; Chiocci, F.L. Formation of an 'a'ā lava delta: Insights from time-lapse multibeam bathymetry and direct observations during the Stromboli 2007 eruption. Bull. Volcanol. 2014, 76. [CrossRef]

7. Casalbore, D.; Romagnoli, C.; Pimentel, A.; Quartau, R.; Casas, D.; Ercilla, G.; Hipolito, A.; Sposato, A.; Chiocci, F.L. Volcanic, tectonic andmass-wasting processes offshore Terceira island (Azores) revealed by high-resolution seafloor mapping. Bull. Volcanol. 2015, 77. [CrossRef]

8. Casalbore, D.; Bosman, A.; Romagnoli, C.; Chiocci, F.L. Large-scale seafloor waveforms on the flanks of insular volcanoes (Aeolian Archipelago, Italy), with inferences about their origin. Mar. Geol. 2014, 355, 318-329. [CrossRef] 
9. Urgeles, R.; Canals, M.; Baraza, J.; Alonso, B.; Masson, D. The most recent megalandslides of the Canary Islands: El Golfo debris avalanche and Canary debris flow, west El Hierro Island. J. Geophys. Res. Solid Earth 1997, 102, 20305-20323. [CrossRef]

10. Oehler, J.F.; Lénat, J.F.; Labazuy, P. Growth and collapse of the Reunion Island volcanoes. Bull. Volcanol. 2008, 70, 712-742. [CrossRef]

11. Silver, E.; Day, S.; Ward, S.; Hoffmann, G.; Llanes, P.; Driscoll, N.; Appelgate, B.; Saunders, S. Volcano collapse and tsunami generation in the Bismarck Volcanic Arc Papua New Guinea. J. Volcanol. Geotherm. Res. 2009, 186, 210-222. [CrossRef]

12. Casalbore, D.; Romagnoli, C.; Bosman, A.; Chiocci, F.L. Potential tsunamigenic landslides at Stromboli Volcano (Italy): Insight from marine DEM analysis. Geomorphology 2011, 126, 42-50. [CrossRef]

13. Quartau, R.; Trenhaile, A.S.; Mitchell, N.C.; Tempera, F. Development of volcanic insular shelves: Insights from observations and modelling of Faial Island in the Azores Archipelago. Mar. Geol. 2010, 275, 66-83. [CrossRef]

14. Quartau, R.; Hipolito, A.; Romagnoli, C.; Casalbore, D.; Madeira, J.; Tempera, F.; Roque, C.; Chiocci, F.L. The morphology of insular shelves as a key for understanding the geological evolution of volcanic islands: Insights from Terceira Island (Azores). Geochem. Geophy. Geosyst. 2014, 15, 1801-1826. [CrossRef]

15. Romagnoli, C. Characteristics and morphological evolution of the Aeolian volcanoes from the study of submarine portions. In The Aeolian Islands Volcanoes; Geological Society of London: London, UK, 2013; pp. 13-26.

16. Romagnoli, C.; Jakobsson, S.P. Post-eruptive morphological evolution of island volcanoes: Surtsey as a modern case study. Geomorphology 2015, 250, 384-396. [CrossRef]

17. Romagnoli, C.; Casalbore, D.; Ricchi, A.; Lucchi, F.; Quartau, R.; Bosman, A.; Tranne, C.A.; Chiocci, F.L. Morpho-bathymetric and seismo-stratigraphic analysis of the insular shelf of Salina (Aeolian archipelago) to unveil its Late-Quaternary geological evolution. Mar. Geol. 2018, 395, 133-151. [CrossRef]

18. Chiocci, F.L.; Orlando, L. Lowstand terraces on Tyrrhenian Sea steep continental slopes. Mar. Geol. 1996, 134, 127-143. [CrossRef]

19. Pepe, F.; Bertotti, G.; Ferranti, L.; Sacchi, M.; Collura, A.M.; Passaro, S.; Sulli, A. Pattern and rate of post-20 ka vertical tectonic motion around the Capo Vaticano Promontory (W Calabria, Italy) based on offshore geomorphological indicators. Quat. Int. 2014, 322, 85-98. [CrossRef]

20. Casalbore, D.; Falese, F.; Martorelli, E.; Romagnoli, C.; Chiocci, F.L. Submarine depositional terraces in the Tyrrhenian Sea as a proxy for paleo-sea level reconstruction: Problems and perspective. Quat. Int. 2017, 439, 169-180. [CrossRef]

21. Lobo, F.J.; Fernandez-Salas, L.M.; Hernandez-Molina, F.J.; Gonzalez, R.; Dias, J.M.A.; Díaz del Río, V.; Somoza, L. Holocene highstand deposits in the Gulf of Cadiz, SW Iberian Peninsula: A high-resolution record of environmental changes. Mar. Geol. 2005, 219, 119-141. [CrossRef]

22. Chiocci, F.L.; Romagnoli, C. Terrazzi Deposizionali Sommersi Nelle Isole Eolie. Available online: http: / / www.isprambiente.gov.it/contentfiles/00002400/2434-terrazzi-chiocci3.zip/at_download/file (accessed on 10 December 2017).

23. Mitchell, N.C.; Masselink, G.; Huthnance, J.M.; Fernandez-Salas, L.M.; Lobo, F.J. Depths of modern coastal sand clinoforms. J. Sediment. Res. 2012, 82, 469-481. [CrossRef]

24. Bosman, A.; Casalbore, D.; Anzidei, M.; Muccini, F.; Carmisciano, C.; Chiocci, F.L. The first ultra-high resolution digital Terrain model of the shallow-water sector around Lipari Island (Aeolian Islands, Italy). Ann. Geophys. 2015, 58, 771-787.

25. Ventura, G. Kinematics of the Aeolian volcanism (Southern Tyrrhenian Sea) from geophysical and geological data. In The Aeolian Islands Volcanoes; Geological Society of London: London, UK, 2013; pp. 3-11.

26. Lucchi, F.; Gertisser, R.; Keller, J.; Forni, F.; De Astis, G.; Tranne, C.A. Eruptive history and magmatic evolution of the island of Salina (central Aeolian archipelago). In The Aeolian Islands Volcanoes; Geological Society of London: London, UK, 2013; pp. 155-211.

27. Casalbore, D.; Bosman, A.; Romagnoli, C.; Chiocci, F.L. Morphological map of Salina offshore (Southern Tyrrhenian Sea). J. Maps 2016, 12, 725-730. [CrossRef]

28. Chiocci, F.L. Distorsioni nella forma dei TDS rilevati dai profili sismici e ripristino delle corrette geometrie (migrazione). In Atlante dei Terrazzi Deposizionali Sommersi Lungo le Coste Italiane; Memorie Descrittive della Carta Geologica d'Italia: Roma, Italy, 2004. 
29. Bintanja, R.; van de Wal, R.S.W.; Oerlemans, J. Modelled atmospheric temperatures and global sea levels the past million years. Nature 2005, 437, 125-128. [CrossRef] [PubMed]

30. Casalbore, D.; Bosman, A.; Martorelli, E.; Sposato, A.; Chiocci, F.L. Mass-wasting features on the submarine flanks of Ventotene volcanic edifice (Tyrrhenian Sea, Italy). In Submarine Mass Movements and Their Consequences, 6th International Symposium; Springer: Berlin, Germany, 2016.

31. Hernandez-Molina, F.J.; Fernandez-Salas, L.M.; Lobo, F.J.; Somoza, L.; Díaz del Río, V.; Alveirinho Dias, J.M. The infralittoral prograding wedge: A new largescale progradational sedimentary body in shallow marine environments. Geo-Mar. Lett. 2000, 20, 109-117. [CrossRef]

32. Chiocci, F.L.; Casalbore, D. Unexpected fast rate of morphological evolution of geologically-active continental margins during Quaternary: Examples from selected areas in the Italian seas. Mar. Pet. Geol. 2017, 82, 154-162. [CrossRef]

33. Bárcenas, P.; Lobo, F.J.; Macías, J.; Fernández-Salas, L.M.; López-González, N.; Díaz del Río, V. Submarine deltaic geometries linked to steep, mountainous drainage basins in the northern shelf of the Alboran Sea: Filling the gaps in the spectrum of deltaic deposition. Geomorphology 2015, 232, 125-144. [CrossRef]

34. Lambeck, K.; Antonioli, F.; Anzidei, M.; Ferranti, L.; Leoni, G.; Scicchitano, G.; Silenzi, S. Sea level change along the Italian coast during the Holocene and projections for the future. Quat. Int. 2011, 232, 250-257. [CrossRef]

35. Budillon, F.; Esposito, E.; Iorio, M.; Pelosi, N.; Porfido, S.; Violante, C. The geological record of storm events over the last 1000 years in the Salerno Bay (Southern Tyrrhenian Sea): New proxy evidences. Adv. Geosci. 2005, 2, 123-130. [CrossRef]

36. Sabatier, P.; Dezileau, L.; Colin, C.; Briqueu, L.; Bouchette, F.; Martinez, P.; Siani, G.; Raynal, O.; Von Grafenstein, U. 7000 years of paleostorm activity in the NW Mediterranean Sea in response to Holocene climate events. Quat. Res. 2012, 77, 1-11. [CrossRef]

37. Trincardi, F.; Field, M.E. Geometry, lateral variation, and preservation of downlapping regressive shelf deposits: Eastern Tyrrhenian Sea margin, Italy. J. Sediment. Petrol. 1991, 61, 775-790.

38. Anzidei, M.; Esposito, M.; Benini, M. Evidence of active subsidence at Basiluzzo island (Aeolian islands, southern Italy) inferred from a Roman age wharf. Quat. Int. 2014, 288, 158-167. [CrossRef]

39. Calanchi, N.; Lucchi, F.; Pirazzoli, P.; Romagnoli, C.; Tranne, C.A.; Radtke, U.; Reyss, J.L.; Rossi, P.L. Late Quaternary relative sea-level changes and vertical movements at Lipari (Aeolian islands). J. Quat. Sci. 2002, 17, 459-467. [CrossRef]

40. Anzidei, M.; Bosman, A.; Casalbore, D.; Tusa, S.; La Rocca, R. New insights on the subsidence of Lipari island (Aeolian islands, southern Italy) from the submerged Roman age pier at Marina Lunga. Quat. Int. 2016, 401, 162-173. [CrossRef]

41. Anzidei, M.; Bosman, A.; Carluccio, R.; Casalbore, D.; D’Ajello, C.F.; Esposito, A.; Nicolosi, I.; Pietrantonio, G.; Vecchio, A.; Carmisciano, C.; et al. Flooding scenarios in coastal volcanic areas due to land subsidence and sea level rise: A case study for Lipari Island (Italy). Terra Nova 2017, 29, 44-51. [CrossRef]

42. Casalbore, D.; Romagnoli, C.; Bosman, A.; Anzidei, M.; Chiocci, F.L. Coastal hazard due to submarine canyons in active insular volcanoes: Examples from Lipari Island (southern Tyrrhenian Sea). J. Coast. Conserv. 2017, 6, 1-11. [CrossRef]

43. Casalbore, D.; Bosman, A.; Chiocci, F.L. Study of recent small-scale landslides in geologically active marine areas through repeated multibeam surveys: Examples from the Southern Italy. In Submarine Mass Movement and Their Consequences; Springer: Berlin, Germany, 2012.

(C) 2018 by the authors. Licensee MDPI, Basel, Switzerland. This article is an open access article distributed under the terms and conditions of the Creative Commons Attribution (CC BY) license (http://creativecommons.org/licenses/by/4.0/). 